\title{
Hypercalcemia. Pathophysiological Aspects
}

\section{I. ŽOFKOVÁ ${ }^{1}$}

${ }^{1}$ Institute of Endocrinology, Prague, Czech Republic

Received April 20, 2015

Accepted July 17, 2015

On-line November 24, 2015

\section{Summary}

The metabolic pathways that contribute to maintain serum calcium concentration in narrow physiological range include the bone remodeling process, intestinal absorption and renal tubule resorption. Dysbalance in these regulations may lead to hyper- or hypocalcemia. Hypercalcemia is a potentionally life-threatening and relatively common clinical problem, which is mostly associated with hyperparathyroidism and/or malignant diseases (90\%). Scarce causes of hypercalcemia involve renal failure, kidney transplantation, endocrinopathies, granulomatous diseases, and the long-term treatment with some pharmaceuticals (vitamin D, retinoic acid, lithium). Genetic causes of hypercalcemia involve familial hypocalciuric hypercalcemia associated with an inactivation mutation in the calcium sensing receptor gene and/or a mutation in the CYP24A1 gene. Furthermore, hypercalcemia accompanying primary hyperparathyroidism, which develops as part of multiple endocrine neoplasia (MEN1 and MEN2), is also genetically determined. In this review mechanisms of hypercalcemia are discussed. The objective of this article is a review of hypercalcemia obtained from a Medline bibliographic search.

\section{Key words}

Hypercalcemia - Primary hyperparathyroidism - Malignancies • Granulomatous diseases • Familiar hypocalciuric hypercalcemia • MEN1 • MEN2

\section{Corresponding author}

I. Zofkova, Institute of Endocrinology, Prague, Czech Republic. E-mail: izofkova@upcmail.cz
Extracellular calcium has a key role in the regulation of a broad spectrum of physiologic functions. Calcium is involved in blood coagulation, muscle contraction and bone calcification. Serum calcium is tightly regulated by interactions between parathyroid hormone $(\mathrm{PTH})$ and $1,25(\mathrm{OH})_{2}$ vitamin $\mathrm{D}\left(1,25(\mathrm{OH})_{2} \mathrm{D}\right)$, which modulate calcium movement at the level of bone, kidneys and intestines. Calcitonim has also some effect, which is immediate on decreasing osteoclast activity, however its importance in human physiology has not been fully elucidated. In bone, both PTH and $1,25(\mathrm{OH})_{2} \mathrm{D}$ stimulate calcium release into the circulation. Additionally, PTH regulates renal capacity to reabsorb calcium and through a negative feedback mechanism that inhibits PTH synthesis in the parathyroid glands. Additionally, PTH activates $1,25(\mathrm{OH})_{2} \mathrm{D}$ production, which increases calcium reabsorption from the intestines. Any deviation of extracellular calcium levels from the physiological triggers a series of hormonal reactions, which lead, via the specific receptors PTHR1 and VDR and return calcemia to physiological values (Lumachi et al. 2011)

Calcium homeostasis in humans is partly controlled by genes, which are associated with monogenic diseases characterized as severe hyper- or hypocalcemia, additionally, they are sometimes associated with slight disturbances in calcium homeostasis, e.g. mutations in the calcium sensing receptor (CaSR) gene (Bonny and Bochud 2014).

$\mathrm{CaSR}$ is a member of the G-protein coupled receptor family and its structure has 3 different domains. The extracellular domain (612 aminoacids) binds extracellular calcium through multiple negative charges 
allowing the CaSR to function as a sensitive detector of extracellular calcium. CaSRs are found in parathyroid secreting cells in parathyroid glands and the cells lining renal tubules, where they modulate intracellular signaling pathways and renal cation handling. Through this pathway CaSRs influence a number of cell functions involved in extracellular fluid regulation, such as parathyroid cells (PTH secretion, cell proliferation and gene expression), as well as kidney tubular cell activity (Christensen et al. 2011). An increase in serum calcium is followed by a decrease in CaSR potential, which supports calcium reabsorption and promotes calcium excretion by the kidneys (reviewed by Hendy et al. 2009). Through regulation of calcium, the kidneys share responsibility for the metabolic balance of calcium together with other competent tissues, such as bone and the gastrointestinal tract, where CaSRs are also expressed, and help insure a narrow range of systemic calcium (Tyler Miller 2013).

Inactivation and/or activation mutations are responsible for familial hypocalciuric hypercalcemia (FHH) and/or autosomal dominant hypocalcemia, respectively. More than 250 inactivating mutations in the $C a S R$ gene, associated with hypercalcemia, have been identified, which shows that the CaSR gene has broad functional variability. The novel inactivating point mutation in the CaSR (on chromosome 3q; codon 972) associated with hypercalcemia was identified by Mastromatteo et al. (2014) and two mutations c.2120A > $\mathrm{T}(\mathrm{E} 707 \mathrm{~V})$ and c.2320G $>\mathrm{A}(\mathrm{G} 774 \mathrm{~S})$ were discovered by Stratta et al. (2014).

The key importance in calcium homeostasis is attributed to Klotho and fibroblast growth factor 23 (FGF23). The alpha-Klotho has been originally identified as aging gene, however this protein has also been shown an effective regulator of ion transport accross the cell membranes. FGF23 (expressed in the kidneys, parathyroid glands and choroid plexus of the brain) is a powerful phosphaturic factor (Shimamura et al. 2012, Sopjani et al. 2014). After binding to alpha-Klotho, FGF23 might play pivotal roles in calcium and phosphate homeostasis (Nabeshima 2008). This postulation is supported by the finding of association between the Klotho gene polymorphisms G395A and hypercalcemia and/or kidney stones (Telci et al. 2011).

FGF23 levels increase early in chronic kidney disease (CKD) in parallel with decline in renal function (Pavik et al. 2013). Alteration of FGF23-Klotho in CKD is implicated as clinical biomarker of CKD progression (Olauson and Larsson 2013). The exact role of Klotho and FGF23 in calcium and phosphate metabolism remains to be further analyzed.

Hypercalcemia in humans is defined as a serum calcium greater than $2 \mathrm{SD}$ above normal mean in a given laboratory. It could be taken in mind, that hypercalcemia may also be artifactual in subjects with high protein binding (e.g. Waldenström's macroglobulinemia). Hypercalcemia could be divided into PTH-mediated (primary hyperparathyroidism caused by parathyroid adenoma, familial hyperparathyroidism, familial hypocalciuric hypercalcemia and malignancies characterized by paraneoplastic PTH overproduction) and PTH-independent variants (humoral hypercalcemia of malignancy, induced by PTHrP and /or $1,25(\mathrm{OH})_{2} \mathrm{D}$, which are synthetized in tumor tissues and hypercalcemia caused by local osteolytic effect (Reagan et al. 2014).

\section{Primary hyperparathyroidism (PHPT)}

As mentioned above, parathyroid glands play a key role in the regulation of the extracellular calcium concentrations. The chief and oxyphil parathyroid cells express the CaSR, which via G-protein, are able to respond to even minute changes in the circulating calcium levels and then modify production of PTH and intracellular calcium mobilization in response (Brown 2002). Primary hyperparathyroidism occurs sporadically, but occasionally as a familial disease. In adenoma of the parathyroid gland, due to somatic mutation in CaSR and resistance of parathyroid cells to extracellular calcium the set-point for extracellular calcium is reset above its normal level. In individual parathyroid adenomas clonal differences indicate that, subpopulations of adenomatous tissue show distinct disease mechanisms (Shi et al. 2014). In heterozygotic adults, mutations in the CaSR activate parathyroid proliferation, which results in a mild increase in calcemia. However homozygous mutation (mostly in neonates) leads to extreme resistance of CaSR to extracellular calcium, which in turn leads to severe hypercalcemia (Brown 2002). The molecular basis of PHPT goes beyond mutations in the CaSR gene. The proliferation of parathyroid cells is stimulated by the D1/PRAD1 gene with the overexpression of D1/PRAD1 oncogene being implicated in $20-40 \%$ of sporadic parathyroid adenomas (Arnold et al. 2002).

Although PHPT occurs sporadically, it may occasionally be a feature of familial multiple endocrine neoplasia (MEN1, MEN2A) or HPT-jaw tumor syndrome (HPT-JT) (reviewd by Nabeshima 2008). At this point we 
need to mention MEN1 with regard to PHPT. MEN1 is an autosomal-dominant tumor syndrome characterized by the occurence of tumors in multiple endocrine tissues, e.g. parathyroid gland (95\%), enteropancretic and/or neuroendocrine system $(50 \%)$ and anterior pituitary gland (40\%) are affected (Agarward 2013). A germlineinactivating mutation in the MEN1 gene is accompanied by a complete loss of function of its product menin. Pathways and interactions of this protein could explain some pathophysiological aspects of MEN1 (Agarward 2013). Adenoma of the parathyroid gland may also accur together with medullary thyroid carcinoma (MEN2A). The syndrome develops based on protooncogene activation of RET kinase in MEN2 gene (reviewed by Arnold et al. 2002, Lips et al. 2012, Kiaer et al. 2006).

Isolated benign familial hyperparathyroidism may be a consequence of a mutation in the $C D K N 1 B$ (MEN4) gene. Furthermore, rare parathyroid carcinomas are associated with mutation in the CDC73/HRPT2 gene (Hendy and Cole 2013). Expression of additional possible hypothetical parathyroid oncogenes and/or tumorsuppressor genes, which could provide better insight into pathophysiology of PHPT, remains to be found and investigated.

PHPT is most frequently diagnosed in the 6th decade, and is three times more common in women. The prevalence of the disease differs in different populations. Eufrazion et al. (2013) in cross-sectional study including 4207 Brazilian subjects found the prevalence of PHPT to be 0.78 , of which $82 \%$ were asymptomatic. This means that a huge number of patients with PHPT are not yet to be identified. The incidence of PHPT differs according to populations. Griebeler et al. (2015) in a sample from the US found an incidence of 86 patients/100 00 persons/year from 1998-2010. Recent research has found increase trend in PHPT incidence. Although the reasons are unclear, it may in part be explained by changes in osteoporosis screening guidelines (Griebeler et al. 2015).

Diagnosis of PHPT is easy, when hypercalcemia and elevated serum PTH levels are present. However, serum calcium levels can range from normal to extremely high life-threatening values. Serum phosphate concentrations due to inhibition of phosphate reabsorption in the proximal tubules are low or low normal. These indices, together with increased serum chloride and urine calcium excretion ( $>400 \mathrm{mg} /$ day), achieve a diagnostic accuracy of 95-98\%. The addition of the 'intact PTH assay' increases accuracy to $99 \%$. In juvenile PHPT, calcemia and calciuria reach higher values at similar concentrations of serum PTH (Roizen and Levine 2014). This phenomenon shows the differences in feedback mechanisms for serum calcium and PTH in children compared to adults.

PHPT is complicated by low bone mass and atraumatic fractures due to extremely activated bone resorption. Moreover, hypercalcemia together with $1,25(\mathrm{OH})_{2} \mathrm{D}$ overproduction promotes calcium deposits in the kidneys, which leads to tubulointerstitial nephritis and/or nephrolithiasis. The increased vasocontriction causes arterial hypertension. Calcium dependent enzymatic activation leads to peptic ulcer or acute pancreatitis, which can also be a serious complication of PHPT (Obermannova et al. 2009).

Common imaging technics, such as ultrasound, can be used in case of hypercalcemia to exclude enlarged parathyroid glands. Another choice is $99 \mathrm{mTc}$-sestamibi scintigraphy (MIBI SPECT/CT). In questionable cases MRI and positron emission tomography (PET) with use of tracer (e.g. F-fluoro-2-deoxyglucose) combined with CT can also be used. Selective venous sampling with measurement of intact PTH levels can be used in patients with persistent or recurrent hypercalcemia.

In patients with parathyroid hyperplasia (mostly in those with vitamin D deficiency and/or resistance to $1,25(\mathrm{OH})_{2} \mathrm{D}$, adenomas of the parathyroid gland can develop (tertiary hyperparathyroidism). Adenomas are often observed in patients with chronic renal failure or after kidney transplantation who fail to achieve of normal calcium and vitamin D homeostasis (Lumachi and Basso 2014).

\section{Normocalcemic primary hyperparathyroidism}

Normocalcemic primary hyperparathyroidism is not extremely rare, although its prevalence and clinical significance are not exactly known (Cusano et al. 2013). Cases of normocalcemic primary hyperparathyroidism with high iPTH levels and osteopenia have been described by Shlapack and Rizvi (2012). However, in such cases, a biphasic chronological time course should be partially expected since normocalcemia may be followed by the development of serious hypercalcemia (Cusano et al. 2013).

\section{Hypercalcemia associated with thyrotoxicosis}

Hypercalcemia may complicate some other endocrinopathies, most frequently thyrotoxicosis. It is 
established that hypercalcemia occurs in one of every five patients with thyrotoxicosis, and hyperparathyroidism was the cause of hypercalcemia in one of seven thyrotoxic patients (Maxon et al. 1968). However, hypercalcemia can also be caused by hyperthyroidism alone. The actions of thyroid hormone on bone are mediated by thyroid receptors $\alpha$ (Williams 2009). Excess thyroid hormone in adults accelerates osteoclast-mediated bone resorption and increases calcium release into the circulation. Mounfoulet et al. (2011) showed that thyroid hormone receptors mediate long-term effects resulting from chronic disorders of thyroid hormone homeostasis. Currently, the mechanism of hypercalcemia in thyrotoxicosis is not completely understood. The response of the skeleton to thyroid hormone is modulated by iodothyronine deiodinase (type 2 and 3), which converts thyroxine into active triiodothyronine and directly regulates bone remodeling (Onigata 2014). However, a causal association between iodothyronine deiodinase activity and calcium homeostasis in thyrotoxic patients has, to date, not been investigated. Nevertheless, a thorough analysis of calcium metabolism, including serum intact PTH and bone mineral density, should be recommended for every patient with thyrotoxicosis.

\section{Hypercalcemia of malignancy}

Cancer-related hypercalcemia represents the common life-threatening metabolic disorder with an extremely bad prognosis. Although hypercalcemia is observed in about $20-30 \%$ of patients with malignancies (e.g. carcinoma of the breasts, ovaries, cervix, and esophagus, and tumors in of head or neck region), it is often underdiagnozed and treated in less than $40 \%$ of hospitalized patients (Radvány et al. 2013). Mechanisms for hypercalcemia resulting from malignancies differ based on the type of tumor, presence of bone metastases and stage of the disease. Hypercalcemia of malignancy could be classified as local osteolytic hypercalcemia and PTHrP and/or $1,25(\mathrm{OH})_{2} \mathrm{D}$ induced disorder. Fundamental factors responsible for development of hypercalcemia in patients with bone metastases are cytokines, which via RANKL activate osteoclast differentiation and bone resorption together with inability to clear calcium through the kidney (Basso et al. 2011). That is why bisphosphonates and/or more effective monoclonal antibody to RANKL, inhibit lysis of bone regions adjacent to the tumor (de Vernejoul 1997, Basso et al. 2011, Kohno 2014).
In patients with poorly differentiated carcinomas, e.g. squamous cell carcinoma of the lung or invasive transitional cell carcinoma of the urinary bladder, immuno-positive PTHrP together with paraneoplastic PTH are produced by the tumor tissue. The mentioned hormones, except for the bone resorbing effects, increase renal calcium reabsorption (Eid et al. 2004). An epidemiological follow-up study showed that after adjusting for covariates, there was a $63 \%$ higher risk for ovarian cancer in hypercalcemic patients, which is why Schwarz and Skinner (2013) presented the hypothesis that hypercalcemia should call attention to an increased risk of ovarian cancer. Tissue PTHrp has also been identified as a cause of hypercalcemia that can complicate lymphoma cases, although in this malignancy overproduction of $1,25(\mathrm{OH})_{2} \mathrm{D}$ vitamin also plays an important role (Maletkovic et al. 2014, Iida et al. 2014, Ding et al. 2015).

\section{Hypercalcemia in myeloma}

In patients with localized, as well as generalized myeloma hypercalcemia and bone loss are typical findings. Osteoclast activating factors (OAFs) and osteoblast inhibitory factors are synthetized by malignant plasma cells directly, or as a consequence of their interaction with the bone marrow microenvironment. OAFs stimulate bone resorption through nuclear factorkappa B ligand (RANKL), macrophage inflammatory protein $1 \alpha$, interleukin 6 and TNF- $\alpha$ that recruit additional osteoclasts and increase calcium release into the circulation. At the same time, Wnt/dickkopf-1 pathway, which is responsible for activation of osteoblasts, is inhibited. Bone destruction, together with lack of bone formation lead to hypercalcemia, bone loss, bone pain and fractures (reviewed by Walker et al. 2014). Similarly, as in other forms of malignant hypercalcemia, bisphosphonates successfully influence bone syndrome and reduce serum calcium levels (reviewed by Hameed $e t$ al. 2014). Potentional drug in treatment of malignant type of hypercalcemia may be cinacalcet modulating CaSR.

Finally, hypercalcemia may help to disclose malignant disease early, even when tumorous symptomatology is still silent. Hypercalcemic crises in patients with malignancies are serious, life-threatening emergencies, which need aggressive treatment. At this place, it is necessary to be mentioned, that hypercalcemia of malignancy could be further agravated by immobilization at the final stages of disease. 
Immobilization induced hypercalcemia occasionally can be severe and develops relatively early (at the end of week 1) (Yusuf et al. 2015).

\section{Hypercalcemia due to granulomatous diseases}

Granulomatous diseases, such as tuberculosis, sarcoidosis, histoplasmosis or granulomatous mycosis fungoides (Iwakura et al. 2013) are rare causes of hypercalcemia, as is silicone-induced granuloma complicating extensive silicone injections (Agrawal et al. 2013). Mechanism is inappropriate production of $1,25(\mathrm{OH})_{2} \mathrm{D}$ by the granulomas. Hypercalcemia is characterized by high serum $1,25(\mathrm{OH})_{2} \mathrm{D}$ and elevated 24-h urine calcium. Granuloma calcifications in stricken tissues or lymph nodes are visible on CT scans (Agrawal et al. 2013). Hypercalcemia can prezent as a lifethreatening hypercalcemic crisis, nephrocalcinosis, artery calcifications or encephalopathy (Yilmaz et al. 2013, Khasawneh et al. 2013), which they should be considered in the differential diagnosis.

\section{The calcium-alkali syndrome}

The syndrome is characterized by renal failure and metabolic alkalosis. Originally the syndrome was observed in patients with peptic ulcers treated for ingestion with large quantities of milk (milk alkali syndrome). However, recently the syndrome has been found in osteoporotic, but otherwise normal adults treated with calcium in excess of 3-4 g/day.

The pathogenesis of calcium-alkali syndrome consists of the interplay between intestine and kidneys. Ingestion of large amounts of calcium-containing pharmaceuticals increases calcium absorption in the intestine. Enhanced calcemia induces constriction of renal arterioles with subsequent decline in glomerular filtration rate and calcium excretion. Besides, the increased calcium concentration, the luminal membrane activates the CaSR in the ascending loop of Henle and the distal convoluted tubules and increases calcium reabsorption via the transient receptor potential vanilloid 5 (TRVP5) channels. Hypercalcemia suppresses parathormone expression and promotes bicarbonate reabsorption. Metabolic alkalosis is further worsened by nausea and subsequent vomiting. After discontinuation of calcium supplementation and infusion of normal saline, hypercalcemia disappears and renal functions return to original values (reviewed by Arroyo et al. 2013, Patel et al. 2013, Fensenfeld and Levine 2006, Riccardi et al. 2010).

\section{Drug induced hypercalcemia}

While normal serum vitamin D levels have been defined as $75 \mathrm{nmol} / 1$, toxic values are defined as $>250 \mathrm{nmol} / \mathrm{l}$. Hypercalcemia caused by vitamin D intoxication is rare and develops mainly in the neonatal or infancy period. Dominant symptoms are dehydration, as a consequence of vomiting, and weight loss. Laboratory examination reveals hypercalcemia, hypercalciuria (urinary calcium/creatinine ratio $\mathrm{mmol} / \mathrm{mmol}>0.5$ ), low serum PTH levels and nephrocalcinosis. A persons genetic background (mutation in the CYP24A1 gene) may modulate the threshold of vitamin $D$ toxicity (and/or sensitivity to vitamin D), and can differ between individuals (Hmami et al. 2014). Therefore, identification of mutations in the CYP24A1 gene may predict toxic response to vitamin $\mathrm{D}$ treatment.

Vitamin A is known for being important for vision; however, it is also important in numerous other systems, including the skeleton. The active form of the vitamin (all-trans-retinoic acid) binds to nuclear receptors $\operatorname{RXR} \beta$ and $\operatorname{RXR} \gamma$, and function as ligand-activated transcription factors. Hypervitaminosis A activates osteoclasts with a subsequent increase in bone resorption and calcium release into the circulation (Henning et al. 2015). Hypercalcemia may be observed in patients treated with high doses of retinoic acid, e.g. in children with chronic kidney disease (Manickavasagar et al. 2015). One case of hypercalcemia has been described by Safi et al. (2014) in a pediatric patient with cystic fibrosis and renal impairment that was supplemented with relatively low doses of vitamin A. Variability around the lowest dosage of vitamin A known to cause hypercalcemia is quite large and the threshold of vitamin A toxicity has not been defined to date.

Hypercalcemia (mostly induced by hyperparathyroidism) complicates the long-term treatment with lithium (Lehmann and Lee 2013). Twigt et al. (2013), using a group of 314 psychiatric patients taking lithium, found the prevalence of hypercalcemia (serum calcium concentration $>2.60 \mathrm{mmol} / \mathrm{l}$ ) to be $15.6 \%$. No cases of hypercalcemia were observed in nonlithium treated patients. Lehmann and Lee (2013) recommend the regular measurement of calcemia and serum PTH in all lithium treated patients at least annually. 
Hypercalcemia could develop in osteoporotic patients treated with recombinant PTH (1-84) in daily practice. Serum calcium correlated with urinary calcium excretion, serum alkaline phosphatase, and $\beta$-CTx in these patients (Luna-Cabrera et al. 2012). Hypercalcemia can also complicate the long-term treatment with thiazide diuretics via increasing calcium reabsorption in the kidney.

\section{Hypercalcemia complicating kidney transplantation}

Hypercalcemia is commonly associated with an acute or progressive decline in renal functions (e.g. renal tubular damage, rhabdomyolysis). In up to 5-25\% of post-transplant patients, calcemia declines during the immediate post-operative phase (months 3-6) and after that independently of the glomerular filtration rate, gradually increases to maximum at month 12 (reviewed by Lumachi et al. 2011).

The pathogenesis of post-transplant hypercalcemia (mostly complicated by vascular calcifications, bone metabolic disease and allograft dysfunction) is often persistent hyperparathyroidism (Evenepol 2013). Pre-transplant predictors of hyperparathyroidism still have not been defined. Nevertheless, Kawarazaki et al. (2011) showed in 39 kidney transplant recipients that calcemia at month 12 correlated with serum pre-transplant intact PTH levels, while phosphatemia correlated with serum FGF23 levels. Thus the best pre-transplant predictors of 12-months post-transplant hypercalcemia and/or hypophosphatemia could hypothetically be intact PTH and FGF23 levels, respectively. The best way to reduce the occurrence of hypercalcemia after kidney transplantation is parathyroidectomy or treatment with cinacalcet (Messa et al. 2011a,b, Muirhead et al. 2014).

\section{Hypercalcemia of pregnancy and lactation}

Hypercalcemia during pregnancy is uncommon, although dangerous from the point of maternal and fetal morbidity, especially when a hypercalcemic crisis develops. It is usually caused by maternal primary hyperparathyroidism. After localization of the adenoma (ultrasonogarphy), surgery during the second trimester becomes the only curative treatment (Dochez and Ducarme 2015).

Hypercalcemia during pregnancy and lactation can also be caused by excessive production of PTHrP, which is physiologically synthetized in the placenta and mammary glands. PTHrp production is under the control of peripheral serotonin (5-OH tryptamine), which is necessary for proper mammary gland function. Genetic ablation of tryptophan hydroxylase 1 (Tph1) at the start of lactation reduces PTHrp synthesis and decreases osteoclast activity and calcemia values in animals. Futhermore, extreme deficiencies in tryptophan hydroxylase may lead to lactation hypocalcemia. The syndrome is treatable with daily injection of 5-hydroxy tryptamine (Laporta et al. 2014). A hypercalcemic crisis after delivery is extremely dangerous. It has been successfully treated using saline infusions and administration of bisphosphonates (Sato 2008).

\section{Genetically coded hypercalcemias}

Approximately $10 \%$ of hypercalcemia cases involve a genetic predisposition. As mentioned above, hypercalcemia due to hyperparathyroidism has been observed in cases of autosomal dominant multiple adenomatosis MEN1 or MEN2. Further form of genetically determined hypercalcemia is familial hypocalciuric hypercalcemia (FHH). It manifests as a benign hereditary autosomal dominant disease associated with inactivating mutations of the CaSR gene. CaSR is responsible for general tissue sensitivity to calcium signaling. The gene is involved in regulation of PTH secretion and renal calcium excretion. In adults, mutations in the CaSR gene is characterized by hypercalcemia and low values of urine the calcium/creatinine ratio $(<0.020)$ (Christiansen et al. 2011). Heterozygote patients are mostly asymptomatic; however, in homozygous patients (mainly neonates), mutations in the CaSR gene results in severe hyperparathyroidism (Morgan et al. 2014). Cases of atypical FHH with hypercalciuria have been described by Mastromateo et al. (2014).

\section{Mutation in the CYP24A1 gene}

Another gene responsible for inborn hypercalcemia is mutation in the CYP24A1 gene, which encodes activity of vitamin D-24-hydroxylase, which transforms $1,25(\mathrm{OH})_{2} \mathrm{D}$ to inactive $24(\mathrm{OH}) \mathrm{D}$. The lossof-function mutation in this gene causes high serum $1,25(\mathrm{OH})_{2} \mathrm{D}$, which together with enhanced sensitivity to vitamin D leads to hypercalcemia. As compared to FHH, 
hypercalciuria develops in these patients. Dufek et al. (2014) described chronic hypercalcemia and kidney disorders in dizygotic siblings with mutations in the CYP24A1 gene. Furthermore, hypercalcemia associated with the loss-of-function mutation in CYP24A1 gene has been described in four Israeli families (Divour et al. 2015). The same late-onset mutation has also been found in adolescent Caucasian man, in whom hypercalcemia was accompanied by inappropriately high serum $1,25(\mathrm{OH})_{2} \mathrm{D}$, low PTH levels, and nephrolithiasis. The long-term follow-up of hypercalcemia, hypercalciuria and recurrent nephrolithiasis has been reported in a homozygous patient with mutation E143del in CYP24A1 gene (Jacobs et al. 2014). Furthermore, genome wide association studies (GWAS) recently identified novel loci for calcium regulation, such as GATA3 and CYP2R1 (Bonny and Bochud 2014). Identification of additional new genes, using GWAS would improve our insight into the complexity of calcium homeostasis.

The last think that needs mentioning is that hypercalcemia is a life threatening condition that can have prolonged asymptomatic state, which may herald the existence of serious, yet still asymptomatic, diseases in their earliest phase. The most common causes of hypercalcemia are PHPT and malignancy, renal failure and inborn disorders. Less common causes of hypercalcemia are granulomatous diseases, thyrotoxicosis, and medications (e.g. vitamin D, lithium, thiazides, etc.).

Malignancy-associated hypercalcemia is a common clinical emergency in oncology, which arises early or during the late phase of a tumor. That is why measurement of calcemia should be a common, routine analysis in internal medicine.

\section{Conflict of Interest}

There is no conflict of interest.

\section{Acknowledgements}

This work was supported by a Czech Ministry of Health project of the Conceptual Development of Research Organization 00023761 (Institute of Endocrinology, Prague).

\section{References}

AGARWAL SK: Multiple endocrine neoplasia type 1. Front Horm Res 41: 1-15, 2013.

AGRAWAL N, ALTINER S, MEZITIS NH, HELBIG S: Silicone-induced granuloma after injection for cosmetic purposes: a rare entity of calcitriol-mediated hypercalcemia. Case Rep Med 2013: 807292, 2013.

ARNOLD A, SHATTUCK TM, MALLYA SM, KREBS LJ, COSTA J, GALLAGHER J, WILD Y, SAUCIER K: Molecular pathogenesis of primary hyperparathyroidism. J Bone Miner Res 17 (Suppl 2): N30-N36, 2002.

ARROYO M, FENVES AZ, EMMETT M: The calcium-alkali syndrome. Proc (Bayl Univ Med Cent) 26: 179-181, 2013.

BASSO U, MARUZZO M, ROMA A, CARMOZZI V, LUISETTO G, LUMACHI F: Malignant hypercalcemia. Curr Med Chem 18: 3462-3467, 2011.

BONNY O, BOCHUD M: Genetics of calcium homeostasis in humans: continuum betwen monogenic diseases and continuous phenotypes. Nephrol Dial Transplant 29 (Suppl 4): iv55-iv62, 2014.

BROWN EM: The pathophysiology of primary hyperparathyroidism. J Bone Miner Res 17 (Suppl 2): N24-N29, 2002.

CHRISTENSEN SE, NISSEN PH, VESTERGAARD P, MOSEKILDE L: Familial hypocalciuric hypercalcemia: a review. Curr Opin Endocrinol Diabetes Obes 18: 359-370, 2011.

CUSANO NE, MAALOUF NM, WANG PY, ZHANG C, CREMERS SC, HANEY EM, BAUER DC, ORWOLL ES, BIELIKIAN JP: Normocalcemic hyperparathyroidism and hypoparathyroidism in two community-based nonreferral populations. J Clin Endocrinol Metab 98: 2734-2741, 2013.

DE VERNEJOUL MC: Role of parathyroid hormone related peptide (PTHrP) in hypercalcemia of malinancy and the development of osteolytic metastases. J Clin Rheumatol 3 (2 Suppl): 109, 1997.

DING L, XIAO X, HUANG L: Peripheral T-cell lymphoma with hypercalcemic crisis as a primary symptom accompanied by polymyositis: a case report and review of the literature. Oncol Lett 9: 231-234, 2015.

DINOUR D, DAVIDOVITS M, AVINER S, GANON L, MICHAEL L, MODAN-MOSES D, VERED I, BIBI H, FRISHBERG Y, HOLTZMAN EJ: Maternal and infantile hypercalcemia caused by vitamin-D-hydroxylase mutations and vitamin D intake. Pediatr Nephrol 30: 145-152, 2015. 
DOCHEZ V, DUCARME G: Primary hyperparathyroidism during pregnancy. Arch Gynecol Obstet 291: 259-263, 2015.

DUFEK S, SEIDL R, SCHMOOK M, ARBEITER K, MÜLLER-SACHERER T, HEINDL-RUSAI K: Intracranial hypertension in siblings with infantile hypercalcemia. Neuropediatrics 46: 49-51, 2014.

EID W, WHEELER TM, SHARMA MD: Recurrent hypercalcemia due to ectopic production of parathyroid hormonerelated protein and intact parathyroid hormone in a single patient with multiple malignancies. Endocr Pract 10: 125-128, 2004.

EUFRAZINO C, VERAS A, BANDEIRA F: Epidemiology of primary hyperparathyroidism and its non-classical manifestations in the City of Recife, Brazil. Clin Med Insighs Endocrinol Diabetes 6: 69-74, 2013.

EVENEPOEL P: Recovery versus persistence of disordered mineral metabolism in kidney transplant recipients. Semin Nephrol 33: 191-203, 2013.

FENSENFELD AJ, LEVINE BS: Milk alkali syndrome and the dynamics of calcium homeostasis. Clin J Am Soc Nephrol 1: 641-654, 2006.

GRIEBELER ML, KEARNS AE, RYU E, HATHCOCK MA, MELTON LJ 3RD, WERMERS RA: Secular trends in the incidence of primary hyperparathyroidism over five decades (1965-2010). Bone 73: 1-7, 2015.

HAMEED A, BRADY JJ, DOWLING P, CLYNES M, O'GORMAN P: Bone disease in multiple myeloma: pathophysiology and management. Cancer Growth Metastasis 7: 33-42, 2014.

HENDY GN, COLE DE: Genetic defects associated with familial and sporadic hyperparathyroidism. Front Horm Res 41: 149-165, 2013.

HENDY GN, GUARNIERI V, CANAFF L: Calcium-sensing receptor and associated diseases. Prog Mol Biol Transpl Sci 89: 31-95, 2009.

HENNING P, HERSCHEL CONAWAY H, LERNER UH: Retinoid receptors in bone and their role in bone remodeling. Front Endocrinol 6: 31, 2015.

HMAMI F, OULMAATI A, AMARTI A, KOTTLER ML, BOUHARROU A: Overdose or hypersensitivity to vitamin D? Arch Pediatr 21: 1115-1119, 2014.

IIDA T, DATOH S, KANETO H, SASAKI H, NAGANAWA Y, ISHIGAMI K, NAKAGAKI S, SHIMIZU H, KONISHI Y, KON S: A case of hypercalcemia associated with parathyroid hormone-related protein produced by the recurrence of B-cell lymphoma of the pancreas. Nihon Shokakibyo Gakkai Zasshi 111: 2163-2173, 2014.

IWACURA T, OHASHI N, TSUJI N, NAITO Y, ISOBE S, ONO M, FUJIKURA T, TSUJI T, SAKAO Y, YASUDA H, KATO A, FUJIYAMA T, TOKURA Y, FULIGAKI Y: Calcitriol-induced hypercalcemia in a patient with granulomatous mycosis fungoides and end-stage renal disease. World J Nephrol 2: 44-48, 2013.

JACOBS TP, KAUFMAN M, JONES G, KUMAR R, SCHLINGMANN KP, SHAPSES S, BIELIZIKIAN JP: A lifetime of hypercalcemia and hypercalciuria, finally explained. J Clin Endocrinol Metab 99: 708-712, 2014.

KAWARAZAKI H, SHIBAGAKI Y, FUKUMOTO S, KIDO R, NAKAJIMA I, FUCHIN OUE S, FUJITA T, FUKAGAWA M, TERAOKA S: The relative role of fibroblast growth factor 23 and parathyroid hormone in predicting future hypophosphatemia and hypercalcemia after living donor kidney transplantation: a 1-year prospective observational study. Nephrol Dial Transplant 26: 2691-2695, 2011.

KHASAVNEH FA, AHMED S, HALLOUSH RA: Progressive disseminated histoplasmosis presenting with cachexia and hypercalcemia. Int J Gen Med 6: 79-83, 2013.

KJAER S, KUROKAWA K, PERRINJAGUET M, ABRESCIA C, IBÁŇEZ CF: Self-association of the transmembrane domain of RET underlies oncogenic activation by MEN2A mutations. Oncogene 25: 70867095, 2006.

LAPORTA J, KEIL KP, WEAVER SR, CRONICK CM, PRICHARD AP, CRENSHAW TD, HEYNE GW, VEZINA CM, LIPINSKI RJ, HERNANDEZ LL: Serotonin regulates calcium homeostasis in lactation by epigenetic activation of hedgehog signaling. Mol Endocrinol 28: 1866-1874, 2014.

LEHMANN SW, LEE J: Lithium-associated hypercalcemia and hyperparathyroidism in the elderly: what do we know? $J$ Affect Disord 146: 151-157, 2013.

LIPS CJ, DREIJERINK KM, HÖPPENER JW: Variable clinical expression in patients with a germline MEN1 disease gene mutation: clues to a genotype-phenotype correlation. Clinics (Sao Paulo) 67 (Suppl 1): 49-56, 2012. 
LUMACHI F, BASSO SM: Pathophysiology and treatment of nonfamilial hyperparathyroidism. Recent Pat CNS Drug Discov 9: 164-172, 2014.

LUMACHI F, MOTTA R, CECCHIN D, AVE S, CAMOZZI V, BASSO SM, LUISETTO G: Calcium metabolism \& hypercalcemia in adults. Curr Med Chem 18: 3529-3536, 2011.

LUNA-CABRERA F, JUSTICIA-RULL EA, CARICOL-PÉREZ MP, SOLER-VIZÁN E, MESA-LÓPEZ CM, RUIZRUIZ MA, DE LA TORRE-LÓPEZ LE: Incidence of hypercalcemia, hypercalciuria and related factors in patients treated with recombinant human parathyroid hormone (1-84). Minerva Med 103: 103-110, 2012.

MALETKOVIC J, ISORENA JP, PALMA DIAZ MF, KORENMAN SG, YEH MW: Multifactorial hypercalcemia and literature review on primary hyperparathyroidism associated with lymphoma. Case Rep Endocrinol 2014: 893134, 2014.

MANICKAVASAGAR B, MCARDLE AJ, YADAV P, SHAW V, DIXON M, BLOMHOFF R, CONNOR GO, REES L, LANDERMANN S, VAN'T HOFF W, SHROFF R: Hypervitaminosis A is prevalent in children with CKD and contributes to hypercalcemia. Pediatr Nephrol 30: 317-325, 2015.

MASTROMATTEO E, LAMACCHIA O, CAMPO MR, CONSERVA A, BAORDA F, CINQUE L, GUARNIERI V, SCILLITANI A, CIGNARELLI M: A novel mutation in calcium-sensing receptor gene associated to hypercalcemia and hypercalciuria. BMC Endocr Disord 14: 81, 2014.

MAXON HR, APPLE DJ, GOLDSMITH RE: Hypercalcemia in thyrotoxicosis. Surg Gynecol Obstet 147: 694-696, 1978.

MESSA P, CAFFORIO C, ALFIERI C: Clinical impact of hypercalcemia in kidney transplant. Int $J$ Nephrol 2011: 906832, 2011a.

MESSA P, ALFIERI C, BREZZI B: Clinical utilization of cinacalcet in hypercalcemic conditions. Expert Opin Drug Metab Toxicol 7: 517-528, $2011 \mathrm{~b}$.

MONFOULET LE, RABIER B, DACQUIN R, ANGINOT A, PHOTSAVANG J, JURDIC P, VICO L, MALAVAL L, CHASSANDE O: Thyroid hormone receptor $\beta$ modulates thyroid hormone effects on bone remodeling and bone mass. J Bone Miner Res 26: 2036-2044, 2011.

MORGAN M, NIELSEN S, BRIXEN K: Familial hypocalciuric hypercalcemia and calcium sensing receptor. Acta Clin Croat 53: 220-225, 2014.

NABESHIMA Y: Discovery of alpha-Klotho and FGF23 unveiled new insight into calcium and phosphate homeostasis. Clin Calcium 18: 923-934, 2008.

OBERMANNOVA B, BANGHOVA K, SUMNIK Z, DVORAKOVA HM, BETKA J, FENCL F, KOLOUSKOVA S, CINEK O, LEBL J: Unusually severe phenotype of neonatal primary hyperparathyroidism due to a heterozygous incativating mutation in the CASR gene. Eur J Pediatr 168: 569-573, 2009.

OLAUSON H, LARSSON TE: FGF23 and Klotho in chronic kidney disease. Curr Opin Nephrol Hypertens 22: 397-404, 2013.

ONIGATA K: Thyroid hormone and skeletal metabolism. Clin Calcium 24: 821-827, 2014.

PATEL AM, ADESEUN GA, GOLDFARB S: Calcium-alkali syndrome in the modern era. Nutrients 5: 4880-4893, 2013.

PAVIK I, JAEGER P, EBNER L, WAGNER CA, PETZOLD K, SPICHTIG D, POSTER D, WUTHRICH RP, RUSSMANN S, SERRA AL: Secreted Klotho and FGF23 in chrocic kidney disease stage 1 to 5: a sequence suggested from a cross-sectional study. Nephrol Dial Transplant 28: 352-359, 2013.

RADVÁNYI I, CSIKÓS A, BALOGH S: The significance of early diagnosis of cancer-related hypercalcemia (in Hungarian). Orv Hetil 154: 1367-1373, 2013.

REAGAN P, PANI A, ROSNER MH: Approach to diagnosis and treatment of hypercalcemia in a patient with malignancy. Am J Kidney Dis 63: 141-147, 2014.

RICCARDI D, BROWN EM: Physiology and pathophysiology of the calcium-sensing receptor in the kidney. Am $J$ Physiol Renal Physiol 298: F485-F499, 2010.

ROIZEN J, LEVINE MA: A meta-analysis comparing the biochemistry of primary hyperparathyroidism in youths to the biochemistry in adults. J Clin Endocrinol Metab 99: 4555-4564, 2014.

SAFI KH, FILBRUN AG, NASR SZ: Hypervitaminosis A causing hypercalcemia in cystic fibrosis. Case report and focused review. Ann Am Thorac Soc 11: 1244-1247, 2014. 
SATO K: Hypercalcemia during pregnancy, puerperium, and lactation: review and case report of hypercalcemic crisis after delivery due to excessive production of PTH-related protein (PTHrP) without malignancy (humoral hypercalcemia of pregnancy). Endocr J 55: 959-966, 2008.

SCHLAPACK MA, RIZVI AA: Normocalcemic primary hyperparathyroidism-characteristics and clinical significance of an emergency entity. Am J Med Sci 343: 163-166, 2012.

SCHWARTZ GG, SKINNER HG: Prospective studies of total and ionized serum calcium in relation to incident and fatal ovarian cancer. Gynecol Oncol 129: 169-172, 2013.

SHI Y, HOGUE J, DIXIT D, KOH J, OLSON JA JR: Functional and genetic studies of isolated cells from parathyroid tumors reveal the complex pathogenesis of parathyroid neoplasia. Proc Natl Acad Sci USA 111: 3092-3097, 2014.

SHIMAMURA Y, HAMADA K, INOUE K, OGATA K, ISHIHARA M, KAGAWA T, INOUE M, FUJIMOTO S, IKEBE M, YUASA K, YAMANAKA S, SUGIURA T, TERADA Y: Serum levels of soluble secreted $\alpha$-Klotho are decreased in the early stages of chronic kidney disease, making it a probable novel biomarker for early diagnosis. Clin Exp Nephrol 16: 722-729, 2012.

SOPJANI M, RINNERTHALER M, ALMILAJI A, AHMETI S, DERMAKU-SOPJANI M: Regulation of cellular transport by klotho protein. Curr Protein Pept Sci 15: 828-835, 2014.

STRATTA P, MERLOTTI G, MUSETTI C, QUAGLIA M, PAGANI A, IZZO C, RADIN E, AIROLDI A, BOARDA F, PALLADINO T, LEONE MP, GUARNIERI V: Calcium-sensing-related gene mutations in hypercalcaemic hypocalciuric patients as differential diagnosis from primary hyperparathyroidism: detection of two novel inactivating mutations in an Italian population: Nephrol Dial Transplant 29: 1902-1909, 2014.

TELCI D, DOGAN AU, OZBEK E, POLAT EC, SIMSEK A, CAKIR SS, YELOGLU HO, SAHIN F: Kotho gene polymorphism of G395A is associated with kidney stones. Am J Nephrol 33: 337-343, 2011.

TWIGT BA, HOUWELING BM, VRIENS MR, REGEER EJ, KUPKA RW, RINKES IH, VALK GD: Hypercalcemia in patiens with bipolar disorder treated with lithium: a cross-sectional study. Int J Bipolar Disord 1: 18, 2013.

TYLER MILLER R: Control of renal calcium, phosphate, electrolyte, and water excretion by the calcium-sensing receptor. Best Pract Res Clin Endocrinol Metab 27: 345-358, 2013.

WALKER RE, LAWSON MA, BUCKLE CH, SNOWDEN JA, CHANTRY AD: Myeloma bone disease: pathogenesis, current treatments and future targets. Br Med Bull 111: 117-138, 2014.

WILLIAMS GR: Actions of thyroid hormones in bone. Endokrynol Pol 60: 380-388, 2009.

YILMAZ R, KUNDAK AA, SEZER T, ÖZER S, ESMERAY H, KAZANCI NÖ: Idiopathic infantile hypercalcemia or an extrapulmonary complication of tuberculosis? Tuberk Torax 61: 43-46, 2013.

YUSUF MB, AKINYOOLA AL, ORIMOLADE AE, IDOWU AA, BADMUS TA, ADEYEMI TO: Determinants of hypercalcemia and hypercalciuria in immobilized trauma patients. Bonekey Rep 4: 709, 2015. 